\title{
LMP-2:419-427 Peptide Vaccine
}

National Cancer Institute

\section{Source}

National Cancer Institute. LMP-2:419-427 Peptide Vaccine. NCI Thesaurus. Code C62768.

A peptide vaccine containing amino acids residues from 419 through 427 of the latent membrane protein-2 (LMP-2) of the Epstein-Barr virus (EBV) with potential immunostimulating and antineoplastic activities. LMP-2, an EBV transmembrane protein, is expressed in various malignancies including nasopharyngeal cancer and EBV-positive Hodgkin disease. Vaccination with the LMP-2:49-427 peptide may boost the immune system to mount a specific cytotoxic T-lymphocyte response against LMP-2 producing cells, resulting in cell lysis and inhibition of cancer cell proliferation. 